\title{
A Cass Stuvx: $\quad$ Seed sector development strategy for AP and Telangana after bifurcation
}

\author{
KARTOORI SAISANTHOSH, K. KESHAVULU, K. JHANSI RANI, RAZIA \\ SULTANA AND P. SUJATHA
}

Article Chronicle : Received : 14.07.2017;

Accepted : 29.07.2017

KeY Words :

Seed sector, Development strategy
SUMMARY : Indian seed Industry development was increased after new policy on seed development, 1988 and introduction of Bt cotton into India. Indian seed industry is comprising of public and private sector organizations is well poised to meet the seed requirements of the country as well as for exports and custom production. The private sector accounts for more than $60 \%$ of the quality seed production of hybrid in cotton, maize, sorghum, bajra, sunflower, forage sorghum etc. and incase of vegetable seed production as much as 90 per cent comes from private producers. The seed valley concept helps to produce quality seeds to meet the requirements of the state, country and also export to other countries directly or through joint ventures. The seed valley will bring related organizations/institutes and departments together in one location to extend services to seed industry various aspects. The good quality seeds supplied by the industry to the farmers within and outside the state has helped for increasing the productivity of different crops and to ameliorate the economic conditions of the farming community. An essential element of any developmental programme for achieving the said goals is evaluation and monitoring. Even though both the states has weaknesses and threats can overcome them by effective planning and management and growth rate can be increased by $12-15 \%$.

How to cite this article : Saisanthosh, Kartoori, Keshavulu, K., Rani, K. Jhansi, Sultana, Razia and Sujatha, P. (2017). Seed sector development strategy for AP and Telangana after bifurcation. Agric. Update, 12(TECHSEAR4): 1168-1174; DOI: 10.15740/HAS/AU/12. TECHSEAR(4)2017/1168-1174.

\section{KARTOORI}

SAISANTHOSH

Professor Jayashankar

Telangana State

Agricultural University, HYDERABAD

(TELANGANA) INDIA

See end of the article for authors' affiliations 